\title{
CHALLENGES AND STRATEGIES THAT ENKINDLE INTEREST IN BASIC SCIENCES
}

\author{
Noeline J. Pinto* \& Roopa S.*
}

The time has dawned for the revival of Basic Sciences. The New Education Policy has recognized the importance of 'teaching' in Higher Education with a new outlook on training, assessment and professionalism. The same trend runs through the highlights of UNESCO (1996) and ministry of HRD (2000).

Basic Sciences should provide a firm foundation at the undergraduate level in acquiring skills and knowledge. For instance a person without a firm footing in structure and functions of DNA cannot engage himself directly in the molecular level studies of DNA. However, the current status of Basic Sciences is rather alarming with the dawn of newer disciplines like Microbiology, Biotechnology, Genetics, Environmental sciences, Information Technology that have gained precedence over Basic sciences. Students have become more demanding with the advent of newer techniques requiring newer skills. It is therefore imperative that basic sciences introduce necessary tools and techniques which provide scope for sound training in various methodologies that orient the students for research, project work helping them to gain knowledge on industrial functioning, managerial skills for employability and help relate education to productivity in keeping with National goals and objectives.

* Department of Botony, St Agnes College, Mangalore - 575002. 
The existing traditional curricula of Basic Sciences have following shortcomings.

a) Basic rather Low-level skills (where there is no scope to cater the needs of neither slow nor giffed learners as they follow a uniform pattern).

b) Neglect of meaningful content (the syllabi are redundant without much thought towards recent trends and techniques).

c) Lacks Higher order thinking (It does not promote higher order thinking and evaluation at the knowledge level of cognitive domain).

The challenge now lies with the basic sciences to adopt new ways of thinking about learning is by adopting a 'Thinking Curriculum' Current Cognitive Research (1989).

This incorporates, HOLISTIC CURRICULUM - that can promote in-depth learning, strategies and skills, creative and critical thinking and content that have social orientation.

- Rigid compartmentalization into conventional subcategories does not represent contemporary concerns. Since the current trend is towards multidisciplinary approach, Basic Sciences should provide a flexible course pattern that is in par with current developments in the scientific world.

* Research oriented - A paradigm shift in curriculum, that would witness a shiff from past-oriented, memory oriented curriculum to futuristic curriculum that would consider current content loaded with future applications as priority areas.

* Entrepreneurship - Upgrading the syllabi would help to fill the missing link between entrepreneurship education and employment. This would also give a solid grounding in core capabilities like communication and managerial skills, co-operative activity etc.

The strategies we have adopted to enkindle the interest in teaching basic sciences are categorized as:

\section{Innovations in Teaching}

Incorporating a teaching strategy based on Goals (why), Content (what) and Methods (how) of teaching and learning.

* Goals are formulated keeping the various Instructional objectives in mind and are written down as specific outcomes of learning (SOL's) lcovering Cognitive, Affective Psychomotor domains]. 
* Content analysis is done using various fechniques, ideally "Davies matrix" [Topic $\rightarrow$ Subtopic $\rightarrow$ sub sub topic $\rightarrow$ Element to be handled per class]

* An appropriate methodology is used to achieve the objectives. Diverse methods are employed that ensure maximum student interaction.

\section{Participative Learning}

The whole process is directed to the needs, capabilities, interests of the pupil who become active recipients of knowledge and skills thereby making it a studentcentred approach.

- Techniques - There are several approaches to encourage participative learning.

- By practicing the 2 cardinal principles of Science - Learning by doing and Learning by living, students imbibe the spirit of scientific enquiry and attitude. This is achieved through 'Projects' with applied aspects where educational content is emphasized, thus promoting widening of mental horizon. E.g.: Paddy - A journey into the oblivion

- We have also evolved a credit-based system called 'Honour's Programme' that provides scope for students to move beyond academics and paves way for positive attire in scientific research.

E.g.: Open Ended Experimentation.

- Following the Heuristic method, the student is kept in the place of a discoverer. This would provide opportunity for the students to become more resourceful by designing experiments and improvising apparatus.

\section{Relate to Learners Background}

Real life issues are focussed and linked to the learner. This sensitizes the learner to the social demands around them. By this they are more likely to seek and value the perspectives of the discipline. To concentrate on this we have organized extension programmes like - Rain Water Harvesting, Sewage Treałment and Housing project for the needy. 


\section{Skill Development}

- A thinking curriculum will help the students to acquire higher order skills like paraphrasing instead of memorizing in traditional curricula.

- Managerial Skills:

- Students become proficient in communicative skills through oral presentations.

- Effective time management to strike a balance between regular curriculum, Honour's programmes, presentations etc.

- Stress is avoided when students are able to do things at the right time.

In conclusion upgrading of basic with relevant tools and techniques, directed towards student-centred learning, general knowledge of subsidiary social behaviour and communication and managerial skills will reflect their personality enabling them to be confident however diverse the field they undertake. 